\title{
Monitoring Costs and Occupational Segregation by Sex: A Historical Analysis
}

\section{Citation}

Goldin, Claudia. 1986. Monitoring Costs and Occupational Segregation by Sex: A Historical Analysis. Journal of Labor Economics 4(1): 1-27.

\section{Published Version}

http://dx.doi.org/10.1086/298091

\section{Permanent link}

http://nrs.harvard.edu/urn-3:HUL.InstRepos:2666727

\section{Terms of Use}

This article was downloaded from Harvard University's DASH repository, and is made available under the terms and conditions applicable to Other Posted Material, as set forth at http:// nrs.harvard.edu/urn-3:HUL.InstRepos:dash.current.terms-of-use\#LAA

\section{Share Your Story}

The Harvard community has made this article openly available.

Please share how this access benefits you. Submit a story.

Accessibility 


\title{
Monitoring Costs and Occupational Segregation by Sex: A Historical Analysis
}

\author{
Claudia Goldin, University of Pennsylvania and National \\ Burean of Economic Research
}

Female manufacturing workers around 1900 were far more likely to be paid by the piece and were rarely employed at the same occupation in the same firm as males. These and related aspects of work organization can be understood through a model in which workers shirk, monitoring is costly, and males and females have different turnover rates. Employers adopt either piece rates or deferred payment. Occupational segregation by sex and differences in earnings result even if workers are equally productive. Establishment-level data on supervising male and female workers in timeand piece-rate positions are examined.

\section{Introduction}

An index of sex segregation across about 300 occupations in the United States has remained roughly constant at 66 from the beginning

This research has benefited from the comments of Stanley Engerman, Robert Margo, and William Sundstrom. The paper took form during informal discussions with Beth Hayes and would have been substantially improved had it not been for her untimely death. An early version was written when the author was a member of the Institute for Advanced Study; a grant from the National Science Foundation has provided support for a larger project on historical aspects of women's work, of which this is a part. This paper has been circulated as NBER Working Paper no. 1560.

[Journal of Labor Economics, 1986, vol. 4, no. 1]

(C) 1986 by The University of Chicago. All rights reserved.

0734-306X/86/0+01-000+\$01.50 
of this century, implying that two-thirds of either the male or the female labor force would have to change occupations to achieve occupational equality (Gross [1968], Blau and Hendricks [1979], and Beller and Han [1984] note a decline in the index during the 1970s). The origins and persistence of occupational segregation by sex have been explained within two general frameworks, one comprising a set of market forces and another a set of norms and ideologies circumscribing female roles. Neither paradigm, however, has yielded a universally accepted framework. It is the contention of this paper that both fail to explain certain aspects of male and female jobs, such as various differences in manufacturing occupations for males and females around the turn of this century and the swift emergence of females in the clerical sector somewhat later. Aspects of supervisory and monitoring costs are explored to understand long-term trends in occupational segregation.

According to the human capital model (Mincer and Polachek 1974; Polachek 1975, 1979, 1981; Zalokar 1982; but see England 1982), individuals choose occupations consistent with their life-cycle labor force participation. Because of their more abbreviated and discontinuous labor force activity, women opt for occupations with lower investment costs and less depreciation with time away from the job than men do. This framework can explain a substantial portion of observed differences in occupations by sex across broadly defined categories, such as professionals and personal service workers. But it does less well in explaining occupational arrangements within groupings.

In terms of long-term trends, the following questions seem to remain only partly answered by the human capital model. Why was there segregation by sex across certain jobs within manufacturing that required similar training and ability? Why were $47 \%$ of all female operatives in manufacturing paid by the piece (or some variant of incentive pay), while only $13 \%$ of all male operatives were paid so in 1890 ? Why were males and females invariably paid by the piece and rarely by time when both worked at the same job in the same firm? Why were males, but rarely females, employed in teams within manufacturing? And of related interest, why do females frequently complain that they are excluded from certain occupations when there are no obvious reasons for entry barriers? Finally, if, as will be demonstrated below, the returns to specific human capital in clerical work were approximately equal for females and males, what accounted for the swift feminization of the clerical sector in the first three decades of this century?

A variant of a shirking model of the Salop and Salop (1976) and Lazear $(1979,1981)$ variety will be employed, although an incentive pay model of the Lazear and Rosen (1981) type is complementary to the analysis. (The model will be contrasted later to a sorting model of the Lazear [in press] variety.) Workers differ only by the amount of time they intend to stay on the job; males remain for two or more periods, 
but females only for one. In all other respects, with the possible exception of reservation wages, these workers are identical. The high cost of supervising the output of workers leads employers to adopt one of two solutions to avoid shirking-piece rates and deferred payment. Because females are not employed in period 2, only piece rates can be used for them; males, however, could prefer deferred payment, which causes their earnings profile to be steeper than otherwise.

Occupational segregation by sex results even if workers are homogeneous with regard to their ability and there are no costs of job investment. Because the monitoring of piece rates may be costlier to use in comparison with deferred payment, but may be cheaper than with ordinary time rates, males can receive higher wages in equilibrium than females. ${ }^{1}$ Lifecycle labor force participation differences between males and females dictate the final result, but individual choice of occupations does not. ${ }^{2}$ Under a reasonable set of assumptions, females would want to be employed in the male sector but would be barred from doing so. The exclusion of females from this sector would be efficient.

Establishment-level and more highly aggregated data for manufacturing around the turn of this century are examined with regard to the costs of supervising and monitoring male and female workers in time- and piece-rate positions. Evidence on piece-rate workers across industries is presented to explore the predictions of the model.

Even though the entire occupational distribution has been widely segregated by sex, certain occupations have "changed sex" over time, and their study can reveal factors fostering segregation. Occupations in the clerical sector underwent this transformation in the early part of this century. The clerical sector was "routinized," as had occurred earlier in manufacturing, enabling employers to hire females (see Goldin and Sokoloff [1982] for a discussion of the division of labor in early nineteenth-century manufacturing). Qualitative and empirical evidence is presented indicating that the cost of supervising workers was reduced, but not the firm-level specificity of human capital as has been claimed.

${ }^{1}$ Added production costs might result from using piece rates. The production process would have to be altered to divide the good into component parts that could be easily counted and checked for quality. The model below will assume that these costs (or benefits in the case of economies from division of labor) are zero.

${ }^{2}$ Turnover, not life-cycle labor force participation, is the actual variable of importance. Women could have discontinuous and abbreviated life-cycle labor force participation but lower turnover than men; that is, their length of time with firms could be longer. Most empirical evidence indicates, however, that women have considerably higher turnover and lower lengths of stay with firms than do men. Lower lengths of stay are evident from late nineteenth-century data on labor market experience (Hannon 1977; Goldin 1980, 1984); lower turnover was evident in the 1920s (see, e.g., Rogers 1929); and lower lengths of stay with firms are observed in 1980 s data from the Current Population Surveys. 
General training, acquired off the job, substituted for on-the-job training and enabled employers to homogenize their labor forces based on various preemployment tests. Secretarial services were thus supervised without the use of more costly piece rates.

\section{A Monitoring Model of Occupational Segregation}

Assume that good $Q$ is the only good produced in the manufacturing sector, and that it can be produced by one of two processes: (I) $Q$ can be divided into $n-1$ parts and put together in an $n$th operation. Each of the parts is made separately, and a piece-rate system of payment can be used to pay labor when output quantity is easily monitored and output quality is not an important variable. (II) Alternatively, $Q$ can be made in one process, possibly using a time-rate system of payment particularly when input quantity can be easily monitored and output quality cannot be ascertained cheaply. Thus there will be $n+1$ occupations if both processes coexist. Examples of goods that have been made by both types of processes simultaneously are coats and cigars, but it is generally the case that when both processes coexist, the goods vary by quality with the higher-quality good made on time. It will be assumed at present, but considered in more detail later, that the nature of the good is independent of the production process.

Also assume that there are two types of labor, $L_{f}$ (female) and $L_{m}$ (male), homogeneous and identical except that $L_{f}$ is in the labor force for only 1 period and $L_{m}$ is in for more than 1 period. They can also differ in their labor supply functions to this industry. It is critical, however, that both types of labor will shirk if their inputs or outputs go unsupervised.

Three combinations of payment and supervision can be used: (1) time rate with supervision of input; (2) piece rate with supervision of output; and (3) time rate with an incentive pay structure having a rising pay scale with time on the job (Salop and Salop 1976; Lazear 1979, 1981; Guasch and Weiss 1981). ${ }^{3}$ Method 3 involves the supervision of input

\footnotetext{
${ }^{3}$ The models in each of these articles differ from that presented below because each assumes that workers are heterogeneous in some factor relating to work effort or quitting and that the firm cannot determine this difference prior to hiring. The workers in the model below are homogeneous in their productivity and all will shirk if not monitored or given some incentive. But they differ in their turnover, which can be easily determined by the firm. Salop and Salop (1976) assume that workers differ by turnover and that firms cannot distinguish between slow and fast quitters before hiring. Their incentive compatible scheme is to withhold a fraction of earnings from workers in one period that is returned in the next. Guasch and Weiss (1981) assume that workers differ in ability and that, for risk-neutral workers, there always exists a self-selection mechanism in which workers pay for a test that, if passed, gives workers a known return. Lazear (1979) considers the impact of these types of implicit contracts on the
} 
and a monitoring of output. It will be assumed now, and explored empirically later, that the monitoring costs of method 3 are lower than those of method 2, and that the monitoring costs of method 1 are the most expensive. In the model below it is implicitly assumed that there are neither costs nor benefits to dividing the good into component parts; that is, it is costless to invent piece rates and there are no gains from such further division of labor.

The first production process (I) for good $Q$ can be represented by

$$
q_{i}=f_{i}\left(L_{i}, R_{i}, S_{i}\right) \quad i=1, \ldots, n-1,
$$

where $L=$ labor, $R=$ raw materials, and $S=$ supervision. Assume, as well, that this production process is constant returns to scale in $L, R$, and $S$, fixed proportions, and identical across all $i$. Each $q_{i}$ is part of $Q$ such that the joining of the component parts of $Q$ is defined as the $n$th process, $n \mathrm{Q}=q$.

Each laborer on piece rates gets paid the following for each unit of output, under zero profit conditions: $w_{p}=p-s-r$, where $s=$ per unit costs of supervision, and $r=$ per unit costs of raw materials. The price of each piece, $p$, is the price of $Q, P$, divided by $n, p=P / n$. It will be assumed that the price of $Q, P$, is fixed exogenously.

Assume that the supply of labor function for $L_{f}$, defined in terms of the number of pieces produced at each piece rate, is $q=h\left(w_{p}\right)$, where $h^{\prime}$ $>0$, and gives the number of pieces produced per period. As shown in figure 1, when $P=P^{*}$ and the equilibrium piece rate is $w_{p}^{*}$, production will be $q^{*}$ per worker or $k q^{*}$ for all piece workers, if each has an identical piece supply function. That is, $\left(q^{*} / n\right) k=k Q^{*}$ units of the good will be produced. There will be $n$ occupations and $k / n$ persons per occupation. Each worker receives an income of $Y_{p}=q^{*} w_{p}^{*}$ per period worked.

Alternatively, or in conjunction with process $\mathrm{I}$, the industry can use process II, $Q=g(L, R, S)$, also assumed to be constant returns to scale and fixed proportions. In order to compare this production process with that given by process I, we must know the output per period produced by time workers. One assumption is that $k$ time workers, given an amount of monitoring derived below, produce on average exactly what $k$ piece workers do at a wage equivalent to a piece rate of $w_{p}^{*}$. In this case each time worker would have an accepted output standard of $Q^{*} n$ $=q^{*}$ units per time period.

date of voluntary retirement and generates a model of optimal mandatory retirement. Note that there is a close relationship between the results of these models and those of internal labor market theory, although the motivation for each of the constructs might differ. 

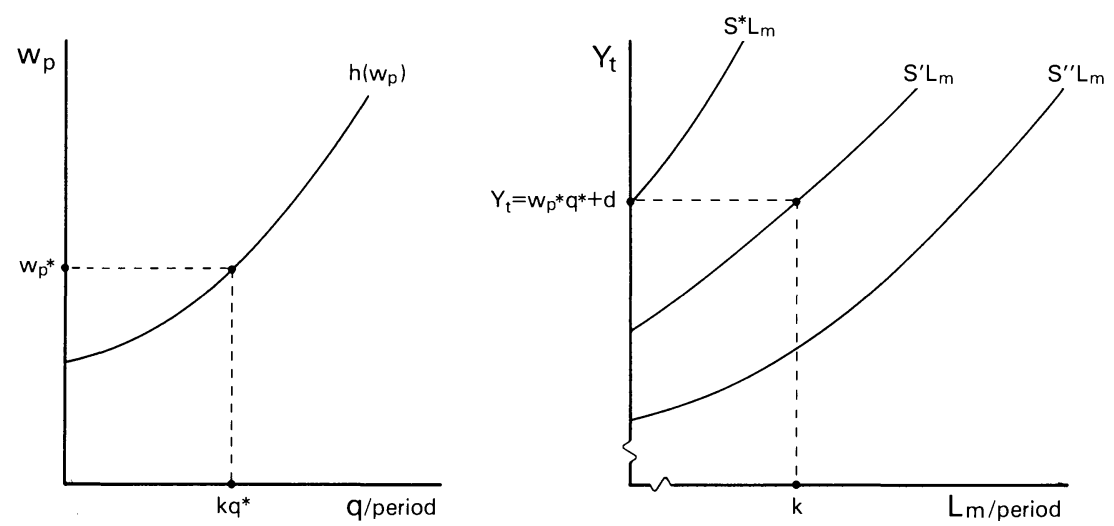

FIG. 1

The zero profit condition implies that each time worker will receive $Y_{t}=\left(P-n r-s^{\prime}\right)(q / n)-t$, where $s^{\prime}$ is the per unit output supervision cost and $t$ is the per time period input supervision cost. The first term in parentheses is the per unit (short-run) profit and the second is the amount of final output produced. The last term, $t$, is the cost per time period of supervising a time worker. ${ }^{4}$ The standardization of the two methods implies that at the existing price of the output, $P^{*}$, there is an $s^{\prime}$ and a $t$ such that $q^{*}$ per worker is elicited per period. At that $s^{\prime}$ and $t$, firms would be indifferent between hiring time and piece-rate workers.

In general, therefore, $Y_{t}=Y_{p}+\left[s q-\left(s^{\prime} q / n\right)-t\right]$, and the difference in the earnings of time and piece workers, to be denoted $d$, depends on the degree to which supervisory costs differ between the two methods. While it seems reasonable that $s q>s^{\prime} q / n$, or that the monitoring of output is cheaper for time workers because there are fewer pieces, it is not clear that the magnitude of $t$ will not swamp this difference. Furthermore, it is not clear whether the costs of monitoring a unit of the piece-rate good are less than the costs of monitoring a unit of the time-rate good, that is, the relationship between $s$ and $s^{\prime}$.

Consider only the first two types of payment and supervision. The costs of monitoring for type 1, time rate with only input supervision, could be sufficiently high that all workers would opt for piece-rate work. That is, $s^{\prime}$ per unit and $t$ per person as supervision costs to elicit $q^{*}$ might be high enough so that $Y_{t}<Y_{p}$, and then all workers would prefer to work on piece. An alternative to piece rates, however, is to

${ }^{4}$ Note that while one could use the time workers to produce using the piecerate technology, it would generally be more expensive to do so because of the added number of pieces to monitor. That is, if $s^{\prime}=s$, supervision costs would be higher employing time workers on the piece-rate technology. 
hire only the $L_{m}$ workers, all of whom will be in the labor force for at least 2 periods, and pay them $Y_{t 1}=\left(w_{p}^{*} q^{*}+d-e\right)<Y_{p}+d$ for period 1, and $Y_{t 2}=\left(w_{p}^{*} q^{*}+d+e\right)>Y_{p}+d$ for period 2, where $d$ $=q^{*}\left[s-\left(s^{\prime} / n\right)\right]-t=\left(Y_{t}-Y_{p}\right), e=$ an optimal deferred payment, and there are zero rates of interest and time preference.

The incentive scheme of facing workers with an upward-sloping wage profile succeeds because employers can easily screen individuals who will not remain in the labor force for 2 periods, and there is sufficient monitoring of output that shirking can be detected prior to period 2. If time workers do not produce the required output level, they are dismissed after the first period and can only be hired in the piece-rate sector in the second period. Because workers value only income, they would rather work in the time-rate sector for both periods when $d>0$. The firm promises to pay workers $Y_{t 2}$ in the second period, giving workers an incentive to produce the required level of output in the first period.

The time-rate experience profile rises with time on the job even though productivity does not. When $d>e$, the $L_{f}$ 's would want to enter the first period time-rate job but are prevented from doing so because the threat of firing them would be of no consequence. The size of $e$ can be determined in a more comprehensive model by two sets of factors, the stability and reputation of the firms and the cost of effort to the workers (see Lazear [1979, 1981] for the determinants of the optimal profile). Note that when $d>0$, the $L_{m}$ 's receive higher lifetime average income than do the $L_{f}$ 's, when all $n+1$ occupations exist. This result holds even though all labor is intrinsically of equal productivity and even if $d<e$ or the deferred payment is greater than the difference in supervision costs.

A final issue concerns the conditions under which both types of workers, and thus both processes (comprising the $n+1$ occupations), will coexist and, if so, which workers are assigned to which processes. The answer depends on the supply of labor. In the piece-work case, it was assumed that all labor was identical, and thus that $h\left(w_{p}\right)$, as drawn in figure 1, was an aggregate of the individual functions, all identical. For time work, however, the simplest case would be one in which the reservation wage for each worker differs, and thus the supply function gives the number of laborers supplied per time period at each $Y$. Because only the $L_{m}$ 's will ever be chosen to work on the time-rate jobs when $d$ $>0$, time-rate workers will be called $L_{m}$ 's. In the case drawn in figure 1, the supply function $S^{\prime} L_{m}$ happens to lead to an equal number of $L_{m}$ and $L_{f}$ workers; $s^{\prime \prime} L_{m}$ leads to more $L_{m}$ workers; and $s^{*} L_{m}$ results in no $L_{m}$ workers. Thus the ratio $L_{f} / L_{m}$ depends on the position of the male labor supply function and the level of $d$, given the piece-rate supply function. 
When both processes are used and $d>0$, the following results will obtain:

(1) complete occupational segregation by sex;

(2) females will all be paid by the piece and males by time;

(3) the ratio of female to male earnings will be $\left[Y_{p} /\left(Y_{p}+d\right)\right]<1$, on average, although for first-period employees it could be $>1$ if $d<e$; and

(4) if $d>e$, females would want to enter the entry-level $L_{m}$ occupation but will be prevented from doing so.

\section{Monitoring and Supervision in Manufacturing, circa 1890}

Only one type of good existed in the monitoring model, and the method of payment for labor was solely determined by the costs of monitoring and differences in life-cycle employment across workers. In the real world, however, there are other reasons for using different methods of payment that determine the types of goods made by piece and time, the types of workers that will be employed in each process, and their remuneration. Three additional complementary reasons for piece rates must be added concerning the division of labor, the quality of the good, and the variance of required skill across workers. Another rationale for piece rates, distinct from the monitoring explanation set forth here, is that they enable the sorting of heterogeneous workers (Lazear in press). This alternative hypothesis will be explored in the empirical section.

Certain types of goods might be divided into pieces more easily than others, and in these the division of labor itself might reduce per unit costs. In these cases the piece-rate technology might dominate even in the absence of monitoring costs. Alternatively or in conjunction, goods may differ by quality. It is generally presumed that one can monitor output quality more cheaply in low quality goods than in high quality goods (Pencavel 1977). In the latter, one may want to screen workers and hire only those who will produce goods of uniformly high quality output and then supervise only by input. Such was the case in the manufacture of clothing at the turn of this century; high quality coats, for example, were made by skilled tailors working on time, while lower quality coats were made by less skilled operatives working by the piece (see the study of men's ready-made clothing, U.S. Senate [1910-11, vol. 87]).

The last reason for the method of payment concerns the variance in skill level across the various pieces or stages in the production process. When the variation in necessary skill is high, one may want to use the lower skilled operations to screen workers for the higher skilled opera- 
tions. The method of screening might be more complex than merely monitoring the output of workers, the only observable aspect of piecerate work. It may, instead, entail judging the inventiveness of workers, their ability to give orders and respond in a variety of situations. Ranking individuals in an ordinal sense may be far cheaper than grading them absolutely. It has been shown that when workers are risk neutral a rankorder system of prizes can elicit the same effort as a piece-rate system (Lazear and Rosen 1981). Both this variant of the model and that elaborated above imply that males will have a higher variance in earnings than will females (holding productivity constant), and thus it would be true even if males and females were equally productive in a deterministic or expected-value sense.

The relative use of piece work across industries and among firms within an industry may be determined by factors complementing those in the simple supervisory-cost model. The question is whether the division of workers between the two types of payment is determined primarily by differences in supervising workers that arise from differences in life-cycle labor force participation. Within the context of the formal model above, one might observe females producing goods that are cheaper to divide into pieces while males produce other goods by time. Similarly, males might produce the higher quality good, and males might also be employed on time-rate pay in industries that screen workers at one level of production for jobs at another. ${ }^{5}$ How male and female workers are sorted across industries might be related to the costs of supervision given these complementary factors. What are the facts concerning the employment of males and females in industries around the turn of this century?

The data in table 1 indicate that $54 \%$ of all adult male employees in manufacturing in 1890 were in industries in which adult males were over $94 \%$ of the labor force. (Adult males were $79 \%$ of the total manufacturing labor force.) Because virtually all the remaining $6 \%$ who were not adult males were boys, $54 \%$ of all adult male employees in manufacturing could not possibly have been in an occupational-industrial classification in which there were women.

At the same time, $74 \%$ of all female employees were in the industries classified in table 1 as female intensive, those in which adult women were over $30 \%$ of all employees; adding the mixed industries raises the figure to $83 \%$. (Adult women were $18 \%$ of the total manufacturing labor

${ }^{5}$ Other factors that might influence the cost effectiveness of using piece rates, as opposed to time rates, have been suggested in Pencavel (1977), Roummaset and Uy (1980), and Lazear (1981, in press). Piece-rate payment might also dominate when technical change is not very rapid, when there is a large luck component in production or sales, and when there is low variability in the efficiency of complementary inputs. 
Table 1

Sex Segregation and Piece Work among 48 Large Industries, 1890

\begin{tabular}{|c|c|c|c|c|}
\hline & $\begin{array}{c}\% \text { Total } \\
\text { Manufacturing } \\
\text { Labor Force }\end{array}$ & $\begin{array}{l}\% \text { Adult Males } \\
\text { in Labor Force* }\end{array}$ & \multicolumn{2}{|c|}{$\begin{array}{c}\% \text { Adult } \\
\text { Workers } \\
\text { on Piece Rates }\end{array}$} \\
\hline \multicolumn{5}{|l|}{ "Male-intensive" industries: $t \mathbb{0}$} \\
\hline Agricultural implements & .93 & 98 & \multicolumn{2}{|c|}{20.59} \\
\hline \multicolumn{5}{|l|}{ Blacksmithing and } \\
\hline wheelwrighting & 1.08 & 100 & \multicolumn{2}{|c|}{2.65} \\
\hline Boots and shoes, custom work & .75 & 98 & \multicolumn{2}{|c|}{36.34} \\
\hline Brick, tile, clay, and pottery & 2.75 & 94 & \multicolumn{2}{|c|}{3.80} \\
\hline Carpentering & 2.97 & 100 & \multicolumn{2}{|c|}{1.62} \\
\hline Carriages, wagons, and cars & 3.07 & 99 & \multirow{2}{*}{\multicolumn{2}{|c|}{$\begin{array}{l}10.81 \\
41.26\end{array}$}} \\
\hline Cooperage & .52 & 98 & & \\
\hline Flouring and grist mill & 1.35 & 99 & \multicolumn{2}{|c|}{$\begin{array}{r}41.26 \\
2.13\end{array}$} \\
\hline Foundry and machine shop & 5.26 & 99 & \multicolumn{2}{|c|}{10.01} \\
\hline Furniture, factory & 1.36 & 95 & \multicolumn{2}{|c|}{12.79} \\
\hline Iron and steel & 3.24 & 99 & \multicolumn{2}{|c|}{$\begin{array}{l}0 \\
1089\end{array}$} \\
\hline Leather, includes morocco & .90 & 98 & \multirow{2}{*}{\multicolumn{2}{|c|}{$\begin{array}{r}10.89 \\
1.27\end{array}$}} \\
\hline Liquors, malt & .74 & 98 & & \\
\hline \multicolumn{5}{|l|}{ Lumber and other mill } \\
\hline products & 6.07 & 98 & \multicolumn{2}{|c|}{3.47} \\
\hline Lumber, planing & 1.84 & 98 & \multicolumn{2}{|c|}{1.70} \\
\hline Masonry, brick, and stone & 2.30 & 100 & \multicolumn{2}{|c|}{1.76} \\
\hline Painting and paper hanging & 1.19 & 100 & \multirow{2}{*}{\multicolumn{2}{|c|}{$\begin{array}{r}4.94 \\
74\end{array}$}} \\
\hline Plumbing and gas fitting & .90 & 98 & & \\
\hline Saddlery and harness & .64 & 95 & \multicolumn{2}{|c|}{$\begin{array}{r}.74 \\
21.59\end{array}$} \\
\hline Shipbuilding & .55 & 100 & & 58 \\
\hline Slaughtering and meat packing & .86 & 96 & & 53 \\
\hline Timber products & .98 & 99 & & 51 \\
\hline Tin and coppersmithing & .82 & 94 & & 38 \\
\hline & $\%$ Total & $\begin{array}{l}\% \text { Adult } \\
\text { Females }\end{array}$ & $\%$ on $\mathrm{Pie}$ & Rates $\dagger$ \\
\hline & $\begin{array}{l}\text { Manufacturing } \\
\text { Labor Force }\end{array}$ & $\begin{array}{l}\text { in Labor } \\
\text { Force* }\end{array}$ & Females & Males \\
\hline "Female-intensive" industries:ł" & & & & \\
\hline Boots and shoes, factory & 3.00 & 29 & 60.0 & 53.5 \\
\hline Boxes & .40 & 65 & 55.6 & 23.0 \\
\hline Carpets & .60 & 45 & 17.8 & 14.9 \\
\hline Clothing, men's & 3.32 & 49 & 68.1 & 49.2 \\
\hline Clothing, women's & .09 & 63 & 46.8 & 43.2 \\
\hline Confectionary & .06 & 39 & 16.7 & 5.8 \\
\hline Corsets & .02 & 81 & 63.5 & 53.4 \\
\hline Cotton goods & 4.70 & 52 & 73.4 & 31.7 \\
\hline Dressmaking & 1.43 & 97 & & \\
\hline Fruits and vegetables, canning & 1.08 & 48 & 49.9 & 19.8 \\
\hline Furnishing goods, men's & .05 & 74 & 65.7 & 51.7 \\
\hline Gloves and mittens & .02 & 59 & 78.0 & 39.7 \\
\hline Hats and caps & .06 & 34 & 70.2 & 55.3 \\
\hline Hosiery and knit goods & 1.30 & 67 & 63.0 & 21.3 \\
\hline Millinery and lace goods & .03 & 73 & 41.4 & 29.7 \\
\hline Millinery, custom & .05 & 98 & & \\
\hline Shirts & .07 & 79 & 69.4 & 52.6 \\
\hline Silk & 1.08 & 57 & 75.6 & 39.8 \\
\hline Woolen goods & 1.68 & 38 & 76.6 & 26.3 \\
\hline Worsted goods & .09 & 46 & $\ldots$ & $\ldots$ \\
\hline
\end{tabular}


Table 1 (Continued)

\begin{tabular}{|c|c|c|c|c|}
\hline & \multirow{2}{*}{$\begin{array}{c}\text { \% Total } \\
\text { Manufacturing } \\
\text { Labor Force }\end{array}$} & \multirow{2}{*}{$\begin{array}{c}\% \text { Adult } \\
\text { Females } \\
\text { in Labor } \\
\text { Force* }\end{array}$} & \multicolumn{2}{|c|}{$\%$ on Piece Ratest } \\
\hline & & & Females & Males \\
\hline \multicolumn{5}{|l|}{ "Mixed" industries: } \\
\hline Clothing; men's custom & 1.83 & 23 & 54.0 & 56.1 \\
\hline Paper & .63 & 23 & 31.4 & .5 \\
\hline Printing, book and job & 1.23 & 17 & 15.0 & 9.3 \\
\hline Printing, newspaper and periodical & 1.22 & 11 & 19.8 & 18.4 \\
\hline Tobacco & 2.75 & 27 & 64.8 & 65.5 \\
\hline
\end{tabular}

SOURCE.-United States Census Office (1895).

NOTE.-Three dots indicate that the figure for the percentage on piece rates is vastly understated. The understated figure was used in the computation of the percentage of all workers on piece rates biasing downward that for females in particular. The data for cotton goods, silk, and woolens are adjusted for the undercount of pieceworkers in these industries using the more detailed, firm- and occupation-level data in the U.S. Department of Labor (1897). The procedure involved merely counting the number of workers by sex and their method of payment. Tobacco includes cigars and cigarettes; boots and shoes, factory includes rubber. Adult females are $>15$ years old and adult males are $>16$ years old.

* Male and female children comprise a separate category, not included here, and the figures for percent adult males and females do not exhaust the entire labor force.

† The percentage of workers on piece rates includes only operatives and nets out clerical workers and other nonoperatives.

$\ddagger$ Male-intensive, female-intensive, and mixed refer to the actual percentage of males or females in each industry and not to an inherent characteristic of the industry.

Total \% manufacturing labor force in these 23 industries $=38 ; \%$ adult males across all industries $=79 ; \%$ total adult male workers in these 23 industries $=54 ; \%$ adult male workers on piece rates across all industries $=12.9$ (adjusted for the undercount of pieceworkers in the cotton goods, silk, and woolen industries in the 1890 Census of Manufacturing; see Note to this table for procedure).

"Total \% manufacturing labor force in these 25 industries $=27 ; \%$ adult females across all industries $=18$; \% total adult female workers in these 25 industries $=83 ; \%$ adult female workers on piece rates across all industries $=46.9$ (adjusted for the undercount of pieceworkers in the cotton goods, silk, and woolen industries in the 1890 Census of Manufacturing; see Note to this table for procedure).

force and children were $3 \%$.) It is only in the mixed industries, such as tobacco and printing, and very few of the female-intensive industries, such as cotton textiles, that one finds any overlap in male and female occupations within late nineteenth-century industries. In what ways did the female-intensive and mixed industries differ from the others?

In looking at the industries in table 1 that were exclusively male domains, several factors seem apparent in limiting the presence of females. Many of these industries required substantial apprenticeships (e.g., cooperage, masonry, plumbing, shipbuilding, custom boot and shoe making). Still others were physically demanding (e.g., slaughtering, iron and steel, milling). Yet these considerations alone might not explain the almost complete exclusion of females from the list. The method of work organization may also have contributed to the exclusivity of these industries. It should also be pointed out that male earnings were not higher in the male-intensive industries, even adjusting for the more rural location of the male-intensive industries.

It was the method of payment and not the absolute level of wages that differed for males across the three groups of industries. All laborers 
in the female-intensive industries were more frequently paid by the piece. Females were overwhelmingly paid by the piece in comparison with male manufacturing laborers in both the female-intensive and the mixed industries. Finally, the distribution of all male and female manufacturing labor by form of payment underscores the results of the separate industry comparisons.

Firms were surveyed by the 1890 Census of Manufacturing (U.S. Census Office 1895) concerning the number of full-time equivalent workers by sex, age group (adult and child), as well as type of position (clerical, skilled operative, unskilled operative, and piece-rate worker). It is not until 1960 that we again have comparable data for the entire manufacturing sector. The data in the 1890 Census of Manufacturing indicate that $37 \%$ of all adult female manufacturing workers ( $>15$ years) were paid by the piece, but that only $13 \%$ of all adult males ( $>16$ years) were paid so.

But the procedure used in the 1890 census to categorize piece-rate workers severely understates their number. Because so many occupations in the cotton goods, silk, and woolens industries, among others, were piece-rate jobs, the census did not record them as such but instead grouped these employees in the operative category. Only $10.1 \%$ of female employees were listed as being employed on piece-rates in cotton goods. The true figure is considerably higher. ${ }^{6}$

Correcting the incentive-pay employment figures for only three industries reveals that at least $47 \%$ of all female operatives across all industries were paid by the piece while only $13 \%$ of males were.

${ }^{6}$ Stanley Lebergott's chapter in Davis, Easterlin, and Parker (1972) also cites the 1890 Census of Manufacturing figures on piecework without corrections. Pencavel (1977), in turn, uses the Lebergott figures, although with reservations. On the undercount in the census, see U.S. Census Office, Manufacturing Industries, Part 1 (1895, p. 173), which states that "an arbitrary rule was adopted that all pieceworkers whose earnings are limited by the speed of machinery were to be included with those paid a specific amount by the week, the day, or the hour."

${ }^{7}$ Corrections to the cotton goods, silk, and woolens industries were made for both males and females by using data in U.S. Department of Labor (1897), which includes information on certain female-intensive and mixed industries. Maleintensive industries may also have suffered from an underreporting of piece-rate employment. A comparison between data arrayed by industry in the 1885 Census of Massachusetts (Massachusetts Bureau of Statistics of Labor 1888) and those for Massachusetts in the 1890 Manufacturing Census (U.S. Census Office 1895) indicate that certain male-intensive industries did underreport incentive-pay work in the federal census. But the male-intensive industries that had the largest differences between the two censuses were relatively unimportant from a national standpoint (arms, clocks, and instruments). The overall figure for the percentage of all manufacturing laborers employed by incentive pay in Massachusetts was $38.7 \%$ in the 1885 Massachusetts census but only $22.7 \%$ in the 1890 Manufacturing 
Females were therefore 3.5 times more likely than were males to be employed on piece rates. Furthermore, piece-rate payment almost always prevailed when males and females occupied the same position in the same firm. Examples from the textile industry are instructive. In only one out of the six predominantly male occupations in cotton textiles was payment generally made by the piece, but among four in which both men and women were found only one was paid by time.

Female workers predominated in those industries in which piece-rate work was common for all workers. The piece-rate percentages in table 1 are generally low for all the male-intensive industries, but the piecerate percentages are relatively high for males in the female-intensive industries. Females were also employed on piece-rate work with greater frequency than were males within the same industry, and they were invariably employed on piece rates when males occupied the same job title. ${ }^{8}$

Certain institutional mechanisms, such as teams and inside contracting, also distinguish male-intensive industries from female-intensive ones. It appears that the length of stay in the labor force and on the job may have been critical in limiting the employment of women in those industries in which such institutions reduced supervisory costs. Teams were groups of workers organized by a contractor who dealt directly with the firm's managers or owners and who was contracted to produce a certain amount of output or paid by the final piece. The agent in turn hired workers, who were frequently well known to the contractor and to the other members of the team. The type of work performed fell somewhere between an intricate division of labor and a single production process for the good. Teams conserved on supervision costs for management because the contractors had knowledge of the productivity of individual workers and were able to increase effort because of personal

Census. However, the $22.7 \%$ figure increases to $33.3 \%$ when corrections are made for the three industries (plus worsteds) listed above, and additional corrections for other female-intensive and mixed industries could well close the remaining gap between these two censuses.

${ }^{8}$ Why were females and males both employed at piece rates when they were given the same occupational title? One reason may be that males were more productive than were females because the existing technology rewarded their greater strength, or because males had a greater incentive to work more intensively than females. Data from the 1895-96 Report of the Commissioner of Labor (U.S. Department of Labor 1897) indicate that the average ratio of earnings for females to males, when both worked at piece rates at the same firm and at the same occupation, was about 0.8 . If these same workers were employed on time, their earnings would have differed (for a given occupation, at the same experience level, and so on). Even in the late nineteenth century unequal payment by gender for identical work would have damaged labor relations within the firm. 
friendships and kin ties. Teams were generally found only in the maleintensive industries or among male workers in other industries. (See Buttrick [1952], who notes that contractors were frequently paid by the piece; Montgomery [1979], who discusses teams among molders, tailors, and miners; U.S. Senate [1910-11, vol. 87], on male teams within men's ready-made clothing.)

In certain industries, in which virtually no women were employed, various aspects of the process could have been done by unskilled workers, and indeed were done by women during periods of labor shortage, such as World War I. In railroad foundries, for example, women were employed during the war in the production of cores and as machinists. The railroad union protested such employment after the war, claiming that such tasks were an integral part of the apprenticeship program, and that while women could be effectively employed in these areas, they undermined the training and screening of skilled workers (Greenwald 1981, pp. 116-17).

The division of workers into piece- and time-rate work, in the formal model of Section 2, was a function of the costs of supervision and monitoring. Do supervision costs differ in the manner predicted by the observed differences in the form of payment by sex? That is, are supervision costs lower for piece-rate than time-rate workers in femaleintensive industries but higher in male-intensive industries where other methods of monitoring and supervising were available?

Two sets of data having information on the form of payment and the costs of supervision are used to explore this issue. One set, from the 1895-96 Report of the Commissioner of Labor (U.S. Department of Labor 1897), contains firm-level data on female-intensive and mixed industries. ${ }^{9}$ Another, from the 1890 Census of Manufactures (U.S. Census Office 1897, pt. 2), contains city-level observations across all industries. The first set of data has been used for the female-intensive industries and the second for the male-intensive ones, of which only foundries had enough observations and large average firm size by city to be usable. ${ }^{10}$

Six industries-boxes, cigars, clothing, cotton, food, and shoes-were selected from the 1895-96 Report for the female-intensive industries.

9 The 1895-96 Report includes information on approximately 68,000 male and 80,000 female employees, and of the 364 industries listed in the 1890 Census of Manufacturing, $57 \%$ were included in the report. The industries represented in the survey included, on a national scale, $40 \%$ of all male operatives but $96 \%$ of all female operatives, not a surprising finding given that the directive was "to investigate. . . the conditions attending the employment of women and children" (p. 11).

${ }^{10}$ In small artisanal firms, such as existed in cooperage, there was insufficient division of labor to measure the supervisory input. There were often no supervisors or managers enumerated because the artisans supervised themselves. 
These industries differed considerably in the degree to which female workers advanced in jobs over the course of their employment and in the variance in female wages across occupations. Clothing and cotton textiles had the highest variance in wages and, it appears from the qualitative evidence, the greatest degree of occupational shift. Because of these differences, industry form-of-payment dummies have been added to the female-intensive industry regression equation explaining supervisory inputs.

The estimation in table 2 explaining supervisory inputs across firms in female-intensive industries indicates that supervisory costs were lowest for male and female piece-rate workers (except in the clothing and cotton textile industries). Male time workers and female time workers were next in order of lowest supervisory cost. A female time worker, on the margin, required almost eight times the supervisory input as did a female piece-rate worker. A male time worker required just one-third the supervisory input of a female time worker, but almost three times that of a male or female piece-rate worker.

These findings are consistent with the conclusions of the model. Female-intensive industries used piece-rate workers to conserve on supervisory costs. The absolute costs of supervision were nontrivial. The average weekly wage of a male supervisor was about $\$ 25.00$. The marginal female time-rate worker required $0.0440 \times(\$ 25.00)=\$ 1.10$ worth of supervision per week or somewhere between $15 \%$ and $20 \%$ of her weekly earnings (assuming a range of $\$ 5.50$ to $\$ 7.30) .{ }^{11}$ The marginal female piece-rate worker required $0.00578 \times(\$ 25.00)=\$ 0.145$ or only $2 \%-3 \%$ of her weekly earnings.

Are female earnings lower than those of males because of their higher supervisory costs? In terms of the predictions of the model, what is the value of $d=\left(Y_{t}-Y_{p}\right)$ and $\left(Y_{t} / Y_{p}\right)$ ? If all female workers are identical, then they must all receive the same net wage, and the choice between employing them on piece or on time must involve whether the piecerate process is more expensive to employ in terms of dividing the good into its component parts. Under this assumption one can use the value of $\$ 1.10(0.044 \times \$ 25.00)$ as the total weekly supervisory (and/or added

${ }^{11}$ The weekly wage across all (adult) female workers in manufacturing was $\$ 5.30$ in 1890 and about $\$ 6.30$ adjusted for full-time work (Brissenden 1929). The absolute values of the coefficients for the female-intensive equation may be too low because of a downward bias to the dependent variable. The 1895-96 Report of the Commissioner of Labor listed foremen, overseers, inspectors, and so on who were paid wages but rarely listed managerial personnel, presumably salaried, who were engaged in supervision. Such personnel, however, may have been a constant factor across firms and thus downwardly bias only the constant term and not the coefficients of interest. 
Table 2

Supervisory Costs and the Form of Payment, Manufacturing circa 1890 (Dependent Variable: Number of Supervisory Personnel per Firm)

\begin{tabular}{|c|c|c|}
\hline & $\begin{array}{l}\text { Female-Intensive } \\
\text { Industries }\end{array}$ & $\begin{array}{l}\text { Male-Intensive } \\
\text { Industries, Foundries }\end{array}$ \\
\hline Constant & $\begin{array}{l}.6538 \\
(1.67)\end{array}$ & $\begin{array}{r}1.277 \\
(10.98)\end{array}$ \\
\hline \multicolumn{3}{|c|}{ Number of workers per firm: } \\
\hline Male piece rate & $\begin{array}{l}.00506 \\
(.92)\end{array}$ & $\begin{array}{l}.0115 \\
(2.40)\end{array}$ \\
\hline Male time & $\begin{array}{l}.0142 \\
(1.76)\end{array}$ & \\
\hline Skilled & & $\begin{array}{l}.00679 \\
(2.81)\end{array}$ \\
\hline Unskilled & & $\begin{array}{l}.00697 \\
(2.02)\end{array}$ \\
\hline Female piece rate & $\begin{array}{l}.00578 \\
(1.95)\end{array}$ & \\
\hline Female time & $\begin{array}{l}.0440 \\
(3.28)\end{array}$ & \\
\hline \multicolumn{3}{|l|}{ Industry dummies: } \\
\hline Boxes & $.313 \quad(.54)$ & \\
\hline Clothing & $.070 \quad(.11)$ & \\
\hline Food & $-1.261 \quad(1.78)$ & \\
\hline Shoes & $.517 \quad(.70)$ & \\
\hline Cigars & $.019 \quad(.03)$ & \\
\hline \multicolumn{3}{|c|}{ Industry-worker interactions: } \\
\hline Cotton male piece & $-.0019(1.75)$ & \\
\hline Cotton male time & $.0425(1.08)$ & \\
\hline Cotton female piece & $.0047 \quad(.69)$ & \\
\hline Cotton female time & $-.0508(2.81)$ & \\
\hline Clothing male piece & $.0021 \quad(.28)$ & \\
\hline Clothing male time & $.0441(3.91)$ & \\
\hline Clothing female piece & $.0028(.54)$ & \\
\hline Clothing female time & $-.0537(3.38)$ & \\
\hline$R^{2}$ & .936 & .203 \\
\hline Number of observations & 289 & 152 \\
\hline
\end{tabular}

NOTE.-Male-intensive industry, from U.S. Census Office (1895), pt. 2: City Totals. The observations are city-industry cells and have been weighted by $\sqrt{n}$, where $n=$ the number of firms in the city. Femaleintensive industries are from U.S. Department of Labor (1897), where the observation is a firm. $t$-statistics are in parentheses.

production) costs to employing a female and compare it with the value of supervision for a male time worker.

In the female-intensive industry sample, the difference between the marginal requirements of a female and a male time worker was $(0.044$ $-0.0142=0.0298) \times(\$ 25.00)=\$ 0.745$ or between $10 \%$ and $14 \%$ of the female weekly wage. ${ }^{12}$ That is, $d=0.745$, and the ratio of earnings

${ }^{12}$ The coefficients in the male-intensive industry sample are not exactly comparable to those in the female-intensive sample and therefore have not been used in this example. 
of an identically productive female to male would be between $88 \%$ and $91 \%$ (e.g., $5.50 /(5.50+0.745)=88 \%)$. The divergence from one is due entirely to the higher costs of supervising female workers. Because males in female-intensive industries may have been different from males in male-intensive industries in terms of turnover rates, these percentages are probably lower-bound measures of the extent to which differences in monitoring costs widen the male-female earnings gap. Furthermore, when differences in strength or work intensity correlated with gender are accounted for, monitoring costs explain about one-third of the remaining difference between male and female wages. ${ }^{13}$

Consider now the two special female-intensive industries, cotton textiles and clothing. The coefficients for these two industries differ from those of the other four industries in two important ways. Female time workers were relatively inexpensive to supervise but male time workers were considerably more expensive to supervise. Cotton textiles and men's factory-made clothing, like the male-intensive industries, utilized screening on the job. Here screening appears to have taken place within the piece-rate positions. These industries, however, did not offer much job advancement for their male workers, and the supervisory input, therefore, was high for male time-rate jobs. ${ }^{1+}$

The results from the male-intensive industry are different from those for most of the female-intensive industries. Supervisory costs were greatest, at the margin, for the piece-rate workers and were only slightly

${ }^{13}$ The overall ratio of female to male earnings in manufacturing was about 0.6 in 1890. The ratio of female to male earnings in piece-rate work (for the same occupations in the same firms) was about 0.8 (U.S. Department of Labor 1897, printing and tobacco industries). The ratio of 0.8 measures actual physical productivity differences between male and female workers. Thus the true gap between the sexes not accounted for by the physical productivity differences revealed in the piece-rate data is $1-(0.6 / 0.8)=25 \%$, rather than the initial $40 \%$. The piece-rate ratio gives us a reason for handicapping female workers and using a basis ratio of 0.8 instead of 1 . Of the initial gap of 40 percentage points, 15 are due to these differences in physical output and 25 remain. Monitoring costs account for about another eight percentage points of the remaining 25 . An example is instructive: say female earnings are $\$ 6.00$ per week and male earnings are $\$ 10.00$ across all workers, but female and male piece-rate workers earn $\$ 6.00$ and $\$ 7.50$. Monitoring costs narrow the unexplained portion even further. On average the difference in monitoring costs between males and females was $\$ 0.75$, thus increasing the augmented female wage of $\$ 7.50$ to $\$ 8.25$. Therefore, a gap of 17.5 percentage points remains, $1-8.25 / 10$, to be explained by a host of other factors.

${ }^{14}$ The male workers in these industries may very well have been less able or had high turnover and may have been sorted out of the male-intensive industries and those in the female-intensive sector that allowed advancement in wages and position. It should be noted that the firms in the 1895-96 Report were generally large and therefore did not include the outside contracting shops in men's clothing that hired skilled tailors organized into teams. 
higher for the unskilled than for the skilled workers. In the maleintensive industry an additional male piece-rate worker added about the same number of supervisors as did a male time-rate worker in the four female-intensive industries. A male time-rate worker in the male-intensive industry added about the same number of supervisors as did a female or male piece-rate worker in the four female-intensive industries. This reversal of the costs of supervision suggests that the formal model may have captured some of the intrinsic differences between the nature of production and work supervision in the two sets of industries. ${ }^{15}$ Male time workers in male-intensive industries may have been supervised less expensively than were time workers in other industries because they were offered an incentive-compatible contract or worked in teams or were given prizes at certain intervals.

It might also be asked whether the supervisors were male or female and whether the costs of obtaining able supervisors varied across industries. The first question can be easily addressed, but the second will have to await the collection of additional data on the earnings of both the supervisors and the workers. Regression results using the number of supervisors of each gender as the dependent variables indicate that both female and male supervisors were used in the female-intensive industries, but, as might be expected, female supervisors were used almost exclusively to supervise female workers and male piece-rate workers. Female supervisors, however, did not oversee the male time-rate workers, a position, it appears, that was reserved for the male supervisors.

One alternative reason for piece rates is that they are a mechanism for sorting workers on the job. The predictions of the monitoring and the sorting models are somewhat different, and the data in the reports just cited enable some empirical tests of them. Lazear (in press) develops a sorting model of piece rates in which workers are heterogeneous with regard to productivity $(q)$, but each has an identical, alternative wage. In the symmetric form of the model only the distribution of productivity is known to both employee and employer; in the asymmetric form the

${ }^{15}$ Because of problems in scaling the dependent variable, a more cautious interpretation would use only the relative magnitudes of the coefficients. The problem is that the proxy for supervisors in the male-intensive industry data probably excludes a group of foremen and overseers, because it includes only managerial personnel involved in supervision (see also $\mathrm{n}$. 11 above on the biases in the female-intensive industry data). The remaining supervisors were included with the skilled, time workers. Because the census gave a distribution of these workers by earnings, one method for estimating the number of total supervisors would be to use the number of workers above a particular level of earnings. Results using this procedure yield coefficients having the same relative magnitudes as those in table 2 (that is piece $>$ unskilled time $>$ skilled time), but all coefficients are substantially larger. 
employee knows $q$. Piece-rate work entails an added cost of monitoring. The predictions of the model, in general, are that firms will sort workers on piece-rate work and then move them to time, saving the cost of monitoring; in the asymmetric case, the worst workers will opt out of the sorting process and will be employed on time. In the monitoring version of piece-rate work, the workers with the highest turnover (and thus the highest costs of supervising), are put on piece.

While it is difficult to formulate a decisive test of these alternative theories, the employment of almost one-half of all female manufacturing workers on piece rates supports the monitoring-cost story, as does the lower frequency of young and inexperienced workers being hired on piece. ${ }^{16}$ Furthermore, in only very few occupations were both time and piece workers hired by the same firm, while in many more occupations time- and piece-rate workers were hired by different firms. But even in the occupations having both time and piece in separate firms, one form of payment appears to have dominated.

In the tobacco industry, in which piece-rate work was very common, only one nonclerical occupation out of 10 had both piece and time workers being employed together by more than one firm. Piece and time workers were employed in six out of 10 occupations by different firms, although the form of payment was evenly divided in only two of these cases. In the printing industry, in which piece-rate work was less common but the employment of males more extensive, only three out of 28 occupations had both piece and time workers being employed together by more than one firm. Piece and time workers were employed in 11 out of 28 occupations by different firms, although the form of payment was unevenly divided in all these cases. ${ }^{17}$ The monitoring-cost story implies that individual firms would not hire both piece and time workers; the sorting story implies that some firms might hire only time

${ }^{16}$ The 1885 Massachusetts Manufacturing Census (Massachusetts Bureau of Statistics of Labor 1888, pp. 1093-95) contains a somewhat better disaggregation of workers by age than does the federal census, and indicates that $18.6 \%$ of all "day hands" were between 14 and 21 years but that $17.7 \%$ of all "piece hands" were. The volume on the glass industry in a U.S. Senate report on women and child workers (U.S. Senate Documents 1910-11, pp. 419-20) stated that "whenever the work is of a more or less delicate character, and capable of great variations in quality and speed, the piece system is generally preferred. . . . Commonly at such work beginners are paid by the time, but, if adaptability is shown, the piece rate is shortly substituted. It is to this latter fact primarily that the higher earnings of pieceworkers as a class is to be attributed. Their earnings are higher than those of time workers in the same occupation, not so much because of more favorable terms of employment, but because it is the more capable workers who are placed on piece rates."

17 The data are from U.S. Department of Labor (1897) and include both male and female workers 18 years old and over. 
workers but certain firms would have both. Because of the infrequency of occupations having both piece and time workers employed within the same industry, let alone within the same firm, it is difficult to test the predictions of the two models with regard to earnings.

The implications of the formal model also concerned the shape of the female and male earnings functions. The male earnings function would be expected to rise over the two periods while that for females is defined only over one period. Because piece work involves a degree of on-thejob learning, but not necessarily what is usually termed investment, the female earnings profile might be expected to rise initially and then become flat, as assumed in the model.

Empirical work substantiates the claim that male earnings rose more continuously with time on the job but female earnings rose more steeply during the early period of employment. In a study of native-born male manufacturing workers in Michigan around 1890 (Hannon 1977), earnings rose for almost 30 years with time on the job. Studies of female earnings around that period (Goldin 1980; Eichengreen 1984) indicate that earnings rose more steeply for females than for males but peaked considerably earlier. While these findings are consistent with the monitoring model, they are also consistent with a human capital model of occupational segregation. Males may accumulate human capital over a longer period of time than do females, with their wages following their rising productivity. Females, on the other hand, could learn considerably in their early working lives, but decide not to invest in human capital having a longer gestation period. The true test between the two hypotheses, that of human capital and that of monitoring, is whether male productivity advances with their earnings. This test cannot be accomplished for the historical period being studied, but there is evidence for the current period that wages do not necessarily follow marginal products (Lazear and Rosen 1981; Medoff and Abraham 1981).

\section{The "Feminization" of the Clerical Sector}

The clerical sector was rapidly feminized in the early part of this century and ranks today as one of the major employers of women. In 1870 fewer than $3 \%$ of all clerical employees were women, but as early as $1900,30 \%$ were, and by 1930 over $50 \%$ were women. It has been frequently claimed that this "feminization" was the result of technological changes, such as the mechanization of the office. A direct extension of this view is that the firm-specific component of clerical skills declined, particularly with the adoption of the typewriter (Rotella 1981). Nineteenth-century clerks were managers in training, but twentieth-century office typists had very limited occupational advancement. It seems clear that the new techniques and machinery changed the nature of the job and opened the way for the employment of females. 
But was the "feminization" of the office a function of the reduced level of skill required with the division of office work into tasks, or was it a function of a reduced level of supervision needed to elicit some level of output? Here again the human capital model and the monitoring model have similar implications and could provide complementary explanations. But several implications of each are distinct. One is to be found in the history of typing and the attempts by managers to avoid expensive piece-rate payments. The second concerns the returns to specific human capital. If the human capital model of office "feminization" is correct, one should find that females accumulated less firm-specific human capital than did males. Data from a 1940 survey of clerical workers indicate approximately equal returns to time spent with the current firm.

In the early history of the modern office various tasks were paid by the piece. Typewriters in the Graton and Knight Manufacturing Company, for example, were equipped with cyclometers, " 240 depressions of the typewriter keys or space bar [were] equivalent to one point . . 600 points [were] considered base production and each point produced in excess [was] allowed for at the rate of one and one-half cents a point" (Coyle 1928, pp. 23-24). The use of these cyclometers increased the cost of labor, and other cost-saving methods were explored. Piece rates did not prevail, and their decline was a tribute to the ability of employers to pretest employees whose training in commercial and high school courses was completed before job entry. ${ }^{18}$

Monitoring in the office became simpler and cheaper than in the factory, despite the general expectation in the 1920s that the office would develop along factory lines. Employers divided workers into homogeneous groups and paid each a set day rate. Standardization enabled employers to screen workers prior to employment. Commonwealth Edison Company, for example, claimed that its stenographers, typists, and dictaphone operators were "classed by temperament and ability. A dictator when he needs a girl telephones to the central bureau and one is sent who is adapted to his kind of work" (Coyle 1928, p. 23). At the same time, however, managers were aware that the benefits of easily supervised tasks cost them the ability to screen workers for higher level positions and cost them the accumulated human capital necessary to produce such workers. "The modern clerk knows one operation. .... He is, therefore, less prepared for larger responsibility.

${ }^{18}$ Various studies published in the 1920s, utilizing Taylor's scientific methods, indicated the clerical jobs for which managers could effectively screen workers prior to employment and those they could not. See the discussion in Davies (1982), chap. 6. 
... The stenographer from a centralized bureau has no . . . continuous and responsible relationship to any one person" (Coyle 1928, p. 27).

Data from the original surveys of a 1940 Women's Bureau Bulletin of male and female clerical workers are used to analyze the returns to training and education in the context of the earnings function. ${ }^{19}$ The findings in table 3 indicate that the earnings function for females is similar to that thought typical today (Mincer and Polachek 1974). Earnings rise gradually with experience without peaking in the relevant range, education measured in years increases earnings, and "home time" decreases earnings by about $1.5 \%$ per year.

The comparisons with the male-earnings function reveal that returns to total experience in clerical work were far greater for men, while returns to experience with the present firm were lower. Years of education were less valuable for men, although an advanced or special degree was worth more. That is, men accumulated relatively more general human capital on the job than did women, and women accumulated a relatively larger amount of specific human capital. Consider a man and a woman with five continuous years with their first employer, thus only five years of experience. The woman's earnings would increase by $13.4 \%$ because of an increase in general skills, and she would receive an additional $6.6 \%$ because of skills specific to her current firm. The man would receive a $24.5 \%$ increase because of augmented general skills, but a $5.8 \%$ increase because of skills specific to his current firm. ${ }^{20}$

Analyses of the occupations of clerical workers in 1940 and at the time of their first clerical job reinforce the findings on earnings. Men typically began as clerks and rose through the ranks with experience. If they had college degrees, they began and remained in skilled positions. Women, however, were initially placed in jobs by years of education, far more so than were males, and generally remained in their first positions or ones very similar, independent of experience. For example, $70 \%$ of all females who began as stenographers and dictaphone operators remained so to $1940 ; 57 \%$ who began as machine operators also stayed in that position. Both findings are invariant to years of office experience. One important exception to the absence of job advancement is secretaries, who frequently rose through the ranks beginning first as general office clerks. Among males, the situation seems much the reverse. Fully onethird of all the men in 1940 were classed in skilled positions (only 6\% of the females were). One-third of these began in skilled positions,

${ }^{19}$ These data were retrieved from the National Archives. For a discussion of the Women's Bureau Bulletin and the survey from which these data were obtained, see Goldin (1984).

${ }^{20}$ Note that these results are the most generous to the alternative hypothesis. Those using the regressions that exclude the schooling dummies indicate a barely significant and smaller coefficient on the tenure variable for men. 
Table 3

Earnings Functions for Female and Male Clerical Workers, 1940 (Dependent Variable: Log Full-Time Salary)

\begin{tabular}{|c|c|c|c|c|}
\hline \multirow[b]{2}{*}{ Constant } & \multicolumn{2}{|c|}{ Females } & \multicolumn{2}{|c|}{ Males } \\
\hline & $\begin{array}{c}6.078^{*} \\
(.069)\end{array}$ & $\begin{array}{c}6.085^{*} \\
(.083)\end{array}$ & $\begin{array}{c}6.474^{*} \\
(.095)\end{array}$ & $\begin{array}{c}6.518^{*} \\
(.085)\end{array}$ \\
\hline Totexp & $\begin{array}{c}.0290^{*} \\
(.0033)\end{array}$ & $\begin{array}{c}.0290^{*} \\
(.0033)\end{array}$ & $\begin{array}{l}.0518^{*} \\
(.0042)\end{array}$ & $\begin{array}{c}.0535^{*} \\
(.0041)\end{array}$ \\
\hline Totexp ${ }^{2}$ & $\begin{array}{c}-.000453^{*} \\
(.000078)\end{array}$ & $\begin{array}{c}-.000447^{*} \\
(.000080)\end{array}$ & $\begin{array}{c}-.000848^{*} \\
(.000083)\end{array}$ & $\begin{array}{c}-.000889^{*} \\
(.000081)\end{array}$ \\
\hline ExpFirm & $\begin{array}{l}.0135^{*} \\
(.0024)\end{array}$ & $\begin{array}{l}.0133^{*} \\
(.0024)\end{array}$ & $\begin{array}{l}.0081^{* *} \\
(.0042)\end{array}$ & $\begin{array}{l}.0115^{*} \\
(.0027)\end{array}$ \\
\hline Contin & $\begin{array}{l}.142^{*} \\
(.030)\end{array}$ & $\begin{array}{l}.139^{*} \\
(.030)\end{array}$ & $\begin{array}{r}-.0576 \\
(.0615)\end{array}$ & $\begin{array}{c}-.0781 \\
(.0599)\end{array}$ \\
\hline Furlough & $\begin{array}{c}-.0224^{*} \\
(.0097)\end{array}$ & $\begin{array}{c}-.0234^{*} \\
(.0098)\end{array}$ & $\begin{array}{c}-.0413^{*} \\
(.0189)\end{array}$ & $\begin{array}{c}-.0471^{*} \\
(.0186)\end{array}$ \\
\hline Married & $\begin{array}{l}.0131 \\
(.0213)\end{array}$ & $\begin{array}{l}.0149 \\
(.0214)\end{array}$ & $\begin{array}{l}.131^{*} \\
(.030)\end{array}$ & $\begin{array}{l}.119^{*} \\
(.030)\end{array}$ \\
\hline YrsEduc & $\begin{array}{l}.0380^{*} \\
(.0049)\end{array}$ & $\begin{array}{l}.0371^{*} \\
(.0075)\end{array}$ & $\begin{array}{l}.0260^{*} \\
(.0052)\end{array}$ & $\begin{array}{l}.0171^{*} \\
(.00472)\end{array}$ \\
\hline CCDum & & $\begin{array}{l}.031 \\
(.026)\end{array}$ & & $\begin{array}{c}-.014 \\
(.046)\end{array}$ \\
\hline VocGrad & & $\begin{array}{c}.046 \\
(.034)\end{array}$ & & $\begin{array}{l}.149^{*} \\
(.063)\end{array}$ \\
\hline CollDum & & $\begin{array}{l}.054 \\
(.046)\end{array}$ & & $\begin{array}{l}.165^{*} \\
(.037)\end{array}$ \\
\hline HSDum & & $\begin{array}{c}-.007 \\
(.028)\end{array}$ & & $\begin{array}{l}.067^{*} \\
(.030)\end{array}$ \\
\hline Home'Time & $\begin{array}{c}-.0147^{*} \\
(.0051)\end{array}$ & $\begin{array}{c}-.0151^{*} \\
(.0051)\end{array}$ & & \\
\hline$R^{2}$ & .464 & .468 & .643 & .665 \\
\hline Number of Obs & 724 & 724 & 481 & 481 \\
\hline
\end{tabular}

SOURCE.-See Goldin (1984). These data are a sample of original schedules from U.S. Department of Labor, Women's Bureau. "Office Work in Philadelphia, 1940.” Women's Bureau Bulletin no. 188-5 (1942). Record Group 86. Boxes 472-86. National Archives.

NOTES.-Standard errors are in parentheses; ${ }^{*}$ indicates significant at least at the 0.05 level; ${ }^{* *}$ indicates significant at least at the 0.10 level.

Variable Definitions:

Totexp = years since individual began first clerical job

Expfirm = years since individual began work with current employer

Contin $=1$ if years worked with current employer has been continuous

Furlough $=$ number (or proportion) of years individual had been furloughed

Married $=1$ if married

CCDum $\quad=1$ if has a commercial course degree

VocGrad $=1$ if graduated from a vocational school

CollDum $=1$ if graduated from college

HSDum $=1$ if graduated from high school

Home Time $=$ number of years unaccounted for, presumably spent out of the labor force; variable is defined as: Totexp - Expfirm - years spent at other clerical jobs. 
typically those with college educations, but another $40 \%$ rose through the ranks beginning as general office clerks.

The presence of machinery and more task-oriented jobs did not eliminate the accumulation of specific human capital among clerical workers, female or male, but did allow for a finer division of labor. This finer division of labor had two effects. It reduced the amount of on-thejob training, at least compared with that apparently required of nineteenthcentury clerks. But the manner by which jobs were divided and the use of prejob tests suggest that monitoring costs were reduced and that the employment of women in clerical jobs was furthered because such costs were conserved. Thus it appears that women began to be employed in the clerical sector when its jobs could be more finely divided and its output more cheaply monitored.

\section{Concluding Remarks}

The literature on occupational segregation by sex has focused on differences in the types of jobs held by males and females, particularly on those in different sectors of the economy and with emphasis on the degree and nature of the human capital required. But within various industries and even within certain occupations, male and female jobs have differed by the method of payment and the nature of the supervisory and monitoring input necessary to elicit output. The model offered in Section II explored the implications of various types of supervisory and monitoring methods, for which expected time on the job was an important determinant. These implications were explored with data from 1890 to 1940 regarding manufacturing and clerical work. Data from a wide variety of sources were consistent with the notion that females were employed in occupations and paid by methods, in particular piece rates, that conserved on monitoring costs.

During the first half of this century the majority of female workers did have rather abbreviated labor force experiences. The labor force participation rate for white married women was low for all age groups until the 1950s. Most women entered the labor force sometime before they married but at the time of marriage exited the labor force permanently. Thus it appears that the assumption of the model concerning the relative length of stay with firms for the majority of males and females was reasonable.

Because so many women exited from the labor force at the time of marriage in the 1920 s and 1930 s various firms instituted prohibitions against their female employees marrying and had stated policies against hiring married women. One interpretation of such prohibitions is that they served a screening function. Firms wanted to attract women who would remain in the labor force for some period of time, and these prohibitions led to the self-selection of those who planned to marry late 
if at all. These prohibitions emerged at the time the clerical sector was expanding and were used to a great extent in the insurance and banking segments of this industry, a finding consistent with the notion that there were large fixed hiring costs in this sector.

But sometime after 1950 an expanding portion of the female population had rather continuous and lengthy stays in the labor force even after marriage (Goldin 1983; Smith and Ward 1984). The female labor force began to be populated by a more heterogeneous group with regard to life-cycle labor force participation, and an extension of the work here would involve exploring the screening or revealing mechanisms that have been used to ascertain this aspect of employment where hiring costs, shirking, or specific human capital paid, in part, by the employer are important.

\section{References}

Beller, Andrea H., and Han, Kee-ok Kim. "Occupational Sex Segregation: Prospects for the 1980s." In Sex Segregation in the Workplace: Trends, Explanations, Remedies, edited by Barbara F. Reskin. Committee on Women's Employment and Related Social Issues. Washington, D.C.: National Academy Press, 1984.

Blau, Francine, and Hendricks, Wallace. "Occupational Segregation by Sex: Trends and Prospects." Journal of Human Resources 14 (1979): 197-210.

Brissenden, Paul F. Earnings of Factory Workers, 1899 to 1927: An Analysis of Pay-roll Statistics. Washington, D.C.: Government Printing Office, 1929.

Buttrick, John. "The Inside Contract System." Journal of Economic History 12 (Summer 1952): 205-21.

Coyle, Grace. Present Trends in the Clerical Occupations. New York: Woman's Press, 1928.

Davies, Margery W. Woman's Place Is at the Typeweriter: Office Work and Office Workers, 1870-1930. Philadelphia: Temple University Press, 1982.

Davis, Lance; Easterlin, Richard; and Parker, William. American Economic Growth. New York, 1972.

Eichengreen, Barry. "Experience and the Male-Female Earnings Gap in the 1890s." Journal of Economic History 46 (September 1984): 822-34.

England, Paula. "The Failure of Human Capital Theory to Explain Occupational Sex Segregation." Journal of Human Resources 17 (1982): 358-70.

Goldin, Claudia. "The Work and Wages of Single Women, 1870 to 1920." Journal of Economic History 60 (March 1980): 81-89.

- "Life-Cycle Labor Force Participation of Married Women." National Bureau of Economic Research Working Paper no. 1251. Cambridge, Mass.: NBER, December 1983.

- "The Historical Evolution of Female Earnings Functions and 
Occupations." Explorations in Economic History 21 (January 1984): $1-27$.

Goldin, Claudia, and Sokoloff, Kenneth. "Women, Children, and Industrialization in the Early Republic: Evidence from the Manufacturing Censuses, 1820 to 1850." Journal of Economic History 42 (December 1982): 741-74.

Greenwald, Maurine Weiner. Women, War, and Work: The Impact of World War I on Women Workers in the United States. Westport, Conn.: Greenwood Press, 1981.

Gross, Edward. "Plus ça Change . . . : The Sexual Structure of Occupations over Time." Social Problems 16 (Fall 1968): 198-208.

Guasch, J. Luis, and Weiss, Andrew. "Self-Selection in the Labor Market." American Economic Review 71 (June 1981): 275-84.

Hannon, Joan. "The Immigrant in the Promised Land: Human Capital and Ethnic Discrimination in the Michigan Labor Market." Ph.D. dissertation, University of Wisconsin, 1977.

Lazear, Edward P. "Why Is There Mandatory Retirement?" Journal of Political Economy 87 (December 1979): 1261-84.

-. "Agency, Earnings Profiles, Productivity, and Hours Restrictions." American Economic Review 71 (September 1981): 606-20.

- "Salaries and Piece Rates." Journal of Business (in press).

Lazear, Edward P., and Rosen, Sherwin. "Rank-Order Tournaments as Optimum Labor Contracts." Journal of Political Economy 89 (October 1981): 841-64.

Massachusetts Bureau of Statistics of Labor. Census of Massachusetts: 1885. Vol. 2, Manufactures, the Fisheries, and Commerce. Boston, 1888.

Medoff, J. L., and Abraham, K. G. "Are Those Paid More Really More Productive?" Journal of Human Resources 16 (Spring 1981): 186-216.

Mincer, Jacob, and Polachek, Solomon. "Family Investments in Human Capital: Earnings of Women." Journal of Political Economy 82 (March/ April 1974): S76-S108.

Montgomery, David. Workers' Control of America: Studies in the History of Work, Technology, and Labor Struggles. Cambridge: Cambridge University Press, 1979.

Pencavel, John. "Work Effort, on-the-Job Screening, and Alternative Methods of Remuneration." Research in Labor Economics 1 (1977): 225-58.

Polachek, Solomon. "Differences in Expected Post-school Investment as a Determinant of Market Wage Differentials." International Economic Review 16 (June 1975): 451-70.

"Occupational Segregation among Women: Theory, Evidence, and a Prognosis." In Women in the Labor Market, edited by C. Lloyd et al. New York: Columbia University Press, 1979.

. "Occupational Self-Selection: A Human Capital Approach to Sex Differences in Occupational Structure." Review of Economics and Statistics 63 (February 1981): 60-69.

Rogers, Thomas Wesley. "A Comparison of Labor Turnover among Men and Women in Two Large Chicago Companies." Montbly Labor Review 28 (January 1929): 39-41. 
Rotella, Elyce. From Home to Office: U.S. Women at Work, 1871-1930. Ann Arbor, Michigan: UMI Research Press, 1981.

Roummaset, James A., and Uy, Marilou. "Piece Rates, Time Rates, and Teams: Explaining Patterns in the Employment Relation." Journal of Economic Behavior and Organization 1 (December 1980): 343-60.

Salop, J., and Salop, S. "Self-Selection and Turnover in the Labor Market." Quarterly Journal of Economics 90 (November 1976): 619-28.

Smith, James P., and Ward, Michael P. "Women's Wages and Work in the Twentieth Century." Rand Corp. Report. October 1984.

U.S. Census Office. Report on Manufacturing Industries at the Eleventh Census: 1890. Pt. 1, Totals for States and Industries. Pt. 2, Statistics of Cities. Washington, D.C.: Government Printing Office, 1895.

U.S. Department of Labor. Eleventh Annual Report of the Commissioner of Labor, 1895-96: Work and Wages of Men, Women, and Children. Washington, D.C.: Government Printing Office, 1897.

Women's Bureau. "Office Work in Philadelphia, 1940." Women's Bureau Bulletin no. 188-5 (1942). Record Group 86. Boxes 472-86. National Archives.

U.S. Senate. Report on the Condition of Woman and Child Wage-Earners in the United States in Nineteen Volumes. 61st Cong., 2d Sess. S. Docs. 86-104. Washington, D.C.: Government Printing Office, 1910-11.

Zalokar, Catherine Nadja. "A Human Capital Model of Sex Differences in Occupational Distribution and Wages." Ph.D. dissertation, Princeton University, 1982. 